\title{
Arbuscular mycorrhizal fungi and Urochloa brizantha: symbiosis and spore multiplication ${ }^{1}$
}

\author{
Marisângela Viana Barbosa ${ }^{2}$, Daniela de Fátima Pedroso², \\ Flavio Araujo Pinto ${ }^{2}$, Jessé Valentim dos Santos ${ }^{2}$, Marco Aurélio Carbone Carneiro ${ }^{2}$
}

\begin{abstract}
Arbuscular mycorrhizal fungi (AMF) may exhibit distinct behaviors when associated with the same species of host plant, being necessary to understand their ecology, in order to optimize their management and maintenance in germplasm bank. This study aimed to evaluate different AMF associated with Urochloa brizantha (A. Rich.) Stapf by analyzing the symbiosis establishment time, spore multiplication and production of glomalin-related soil protein. The experiment was carried out in a completely randomized design, in a $6 \times 5$ arrangement (five AMF species, non-inoculated control treatment and five evaluation times). The following aspects were analyzed: plant growth, spore multiplication, mycorrhizal colonization and glomalin production. The highest number of spores occurred for Acaulospora longula and $A$. colombiana, exhibiting the highest mycorrhizal colonization at 76 days. The inoculation favored the root growth of $U$. brizantha at 15 days of cultivation, plant height and root dry matter at 60 days and shoot dry matter at 90 days, especially for the Acaulospora species. The inoculation with A. colombiana, A. longula and Paraglomus occultum resulted in increased glomalin at 120 days. Gigaspora margarita and $P$. occultum did not reach the maximum colonization and spore multiplication, indicating that a period of time longer than 120 days of cultivation is necessary.
\end{abstract}

KEYWORDS: Germplasm bank, glomalin, glomeromycota.

\section{INTRODUCTION}

Arbuscular mycorrhizal fungi (AMF) establish a mutualistic symbiotic association with the roots of most plant species, characterized by a functional integration of the plants with the AMF, resulting in bidirectional and simultaneous exchange of metabolites and nutrients between the microsymbiont and the host plant (Parniske 2008, Smith \& Read 2008, Oehl et al. 2009).

\section{RESUMO}

Fungos micorrízicos arbusculares e Urochloa brizantha: simbiose e multiplicação de esporos

Fungos micorrízicos arbusculares (FMA) podem apresentar comportamentos distintos, quando associados à mesma espécie de planta hospedeira, sendo necessário compreender sua ecologia, visando a otimizar o seu manejo e manutenção em banco de germoplama. Objetivou-se avaliar diferentes FMA associados a Urochloa brizantha (A. Rich.) Stapf, analisando-se o tempo de estabelecimento da simbiose, multiplicação de esporos e produção de proteína do solo relacionada a glomalina. O experimento foi conduzido em delineamento inteiramente casualizado, com arranjo 6 x 5 (cinco espécies de FMA, tratamento sem inoculação e cinco épocas de avaliação). Analisaram-se o crescimento das plantas, multiplicação de esporos, colonização micorrízica e produção de glomalina. A maior multiplicação de esporos ocorreu para Acaulospora longula $\mathrm{e}$ A. colombiana, apresentando maior colonização micorrízica aos 76 dias. A inoculação favoreceu o crescimento das raízes de $U$. brizantha a partir de 15 dias, altura das plantas e massa seca das raízes aos 60 dias e massa seca da parte áerea aos 90 dias, com destaque para espécies de Acaulospora. A inoculação com A. colombiana, A. longula e Paraglomus occultum promoveu incremento de glomalina aos 120 dias. Gigaspora margarita e P. occultum não atingiram a máxima colonização e multiplicação dos esporos, indicando ser necessário um período maior que 120 dias de cultivo dos FMA.

PALAVRAS-CHAVE: Banco de germoplasma, glomalina, glomeromycota.

These fungi occupy a vital ecological niche and play key roles for the environmental balance in native or cultivated lands (Bücking et al. 2016). Unlike other microorganism groups, AMF are obligatory biotrophics and require a metabolically-active root system to establish the symbiosis and complete their life cycle, renewing their infective propagules (Smith \& Read 2008, Siqueira et al. 2010).

Due to the obligatory biotrophism, the multiplication of AMF is achieved in axenic in vitro

1. Received: Aug. 20, 2018. Accepted: Mar. 26, 2019. Published: Jun. 18, 2019. DOI: 10.1590/1983-40632019v4954530.

2. Universidade Federal de Lavras, Departamento de Ciência do Solo, Lavras, MG, Brasil. E-mail/ORCID:

mvbarbosa10@gmail.com/0000-0003-3220-3243, danifpedroso@gmail.com/0000-0001-6118-4745, flavioaraujo10@gmail.com/ 0000-0003-2695-4796, jessevalentim@gmail.com/0000-0003-4757-2658, marcocarbone@ufla.br/0000-0003-4349-3071. 
cultivation using transformed roots, or in its classical form, in trap pots cultivated with plants (Selvakumar et al.2018). In vitro cultivation enables the multiplication of viable, pure, decontaminated propagules in a shorter period of time, being effective for multiplication of fast-growing AMF, which establish symbiosis in 3 to 4 days (Dalpe \& Seguin 2010). However, it presents limitations in the AMF development, such as reduced growth and reduced capacity to colonize roots. On the other hand, the AMF multiplication method that uses cultivation trap pots with substrate/soil is widely used, especially for being less artificial and more cost-effective and capable of producing large amounts of highly-efficient inoculants in the mycorrhizal colonization of plant roots (Schlemper \& Stürmer 2014, Selvakumar et al. 2018).

Studies have shown that there is compatibility between AMF and host plants, resulting in a variation in spore multiplication, mycorrhizal colonization, extra-radicular hyphae growth and production of glomalin-related soil protein (Klironomos et al. 2005, Parniske 2008, Smith \& Read 2008, Siqueira et al. 2010). Glomalin is a glycoprotein found in the soil, produced on the hyphae surface and by degradation of the AMF hyphae and spores (Lehmann et al. 2017).

The use of plants of the Urochloa genus for multiplication of FMA in germplasm banks is already widespread, but little is known about the host plant interaction with different species of AMF regarding the symbiosis establishment time, multiplication of infective propagules, mycorrhizal colonization and production of glomalin-related soil protein, therefore, producing different effects on the plant growth and on soil. This information is important for optimizing spore multiplication, management of soilborne AMF, planning of studies on inoculation conducted in the field or in controlled environments, and for keeping these fungi in germplasm banks. Therefore, the hypothesis of this study is that different AMF species may have different behaviors when colonizing the same host plant.

Thus, this study aimed to determine if there is a distinct behavior in the interaction of different AMF species associated with Urochloa brizantha (A. Rich.) Stapf and analyze the time of symbiosis establishment, spore multiplication and glomalinrelated soil protein production.

\section{MATERIAL AND METHODS}

The study was carried out in a greenhouse, from September 2015 to February 2016, in a completely randomized design with split plots and five replications, considering the inoculation with five AMF species (Table 1) and one non-inoculated treatment, and five evaluation times $(15,30,60$, 90 and 120 days after the germination). The AMF were used as available in the AMF collection at the Universidade Federal de Lavras, in Lavras, Minas Gerais state, Brazil.

The substrate consisted of a mixture of $2: 1$ (v/v) of washed sand and Oxisol (USA 1999). The substrate chemical characterization was as it follows: $\mathrm{pH}$ value $($ water $)=5.4 ; \mathrm{H}+\mathrm{Al}=2.9 \mathrm{cmol}_{\mathrm{c}} \mathrm{dm}^{-3}$; $\mathrm{Ca}=1.70 \mathrm{cmol} \mathrm{dm}^{-3} ; \mathrm{Mg}=0.10 \mathrm{cmol} \mathrm{dm}^{-3} ; \mathrm{K}=$ $18 \mathrm{mg} \mathrm{dm}{ }^{-3} ; \mathrm{P}=1.13 \mathrm{mg} \mathrm{dm}^{-3} ; \mathrm{OM}=2.11 \mathrm{dag} \mathrm{kg}^{-1}$. The substrate was autoclaved at $121^{\circ} \mathrm{C}$ for one hour, procedure conducted for two consecutive days, and then transferred to $1-\mathrm{kg}$ capacity pots.

The inoculation was performed by transferring 150 AMF spores to each pot containing inoculum soil, which, in addition to the spores, also contained colonized hyphae and roots, which also act as AMF infective propagules. The inoculum used in this study was obtained by multiplication of AMF in cultivation pots (autoclaved soil) for 180 days. Then, the experiment inoculation was carried out.

Sowing was conducted using Urochloa brizantha (A. Rich.) Stapf seeds, which were

Table 1. Arbuscular mycorrhizal fungi (AMF) species used in this study, identified by a deposit code in the AMF collection of the Universidade Federal de Lavras, in Lavras, Minas Gerais state, Brazil.

\begin{tabular}{llc}
\hline & \multicolumn{1}{c}{ AMF species } & Code \\
\hline Acaulospora colombiana & (Spain \& Schenck) Kaonongbua, Morton \& Bever & 537 UFLA \\
Acaulospora longula & Spain \& Schenck & 242 UFLA \\
Acaulospora morrowiae & Spain \& Schenck & 467 UFLA \\
Gigaspora margarita & Becker \& Hall & 252 UFLA \\
Paraglomus occultum & (Walker) Morton \& Redecker & 438 UFLA \\
\hline
\end{tabular}

* The AFM species were firstly isolated from the Brazilian Savannah biome and propagated in a greenhouse using Urochloa decumbens. 
disinfested in a solution of sodium hypochlorite at $0.5 \%(\mathrm{v} / \mathrm{v})$ during $5 \mathrm{~min}$ and washed with distilled water. Each pot contained 20 seeds and, at 15 days after the germination, the plants were thinned out, remaining 10 plants per pot.

During the conduction of the experiment, $20 \mathrm{~mL}$ of nutrient solution composed of $210 \mathrm{mg} \mathrm{L}^{-1}$ of $\mathrm{N}, 234 \mathrm{mg} \mathrm{L}^{-1}$ of K and $15.05 \mathrm{mg} \mathrm{L}^{-1}$ of P were applied, which corresponded to $50 \%$ of the recommended $\mathrm{P}$ concentration. The pots were randomized, and the substrate was maintained with $60 \%$ of the moisture content of the total pores volume.

The study was carried out during 120 days, with periodic assessments at five times $(15,30,60,90$ and 120 days after the germination). At each of these times, the plants were harvested and the following measurements were made: plant height, root length, shoot dry mass, root dry matter, number of spores, mycorrhizal colonization and easily extractable glomalin-related soil protein.

The number of spores was quantified in $50 \mathrm{~mL}$ of the substrate of each treatment, using the wet sieving method (Gerdemann \& Nicolson 1963) and water centrifugation in water and sucrose solution (Jenkins 1964). Counting was made directly from corrugated plates under stereoscopic microscope.

Mycorrhizal colonization was quantified in 1-g samples of thin roots. The roots were washed, diaphanized with $\mathrm{KOH}(10 \%)$ and $\mathrm{H}_{2} \mathrm{O}_{2}$, acidified with $\mathrm{HCl}(1 \%)$ and stained with Trypan blue in lactoglycerol (0.05 \%) (Phillips \& Hayman 1970). The quantification of colonized roots was achieved by the interaction technique in reticulate plates (Phillips \& Hayman 1970, Giovannetti \& Mosse 1980).

The concentration of easily extractable glomalin-related soil protein was determined using the method proposed by Wright \& Upadhyaya (1998). For this purpose, 1-g soil samples with $8 \mathrm{~mL}$ of sodium citrate solution $(20 \mathrm{mM}$ at $\mathrm{pH} 7.2)$ were autoclaved for $30 \mathrm{~min}$ at $121{ }^{\circ} \mathrm{C}$, then centrifuged $(3,200 \mathrm{rpm} / 20 \mathrm{~min})$, and the glomalin-related soil protein extract was obtained from the soil samples and aggregates (Bradford 1976, Wright \& Upadhyaya 1998). Afterwards, the supernatants were quantified by spectrophotometer following the Bradford (1976) method, and the glomalin-related soil protein concentrations ( $\mathrm{mg} \mathrm{g}^{-1}$ of soil) were estimated using the standard protein curve equation $(\mathrm{y}=0.0082 \mathrm{x}+$ $\left.0.481 ; \mathrm{R}^{2}=0.99 * *\right)$, which was obtained by Bovine
Serum Albumin (BSA) as a purified standard protein (Purin 2005).

Data were subjected to the normality test and, for the mycorrhizal colonization and number of spores, they were transformed into $\log (x+1)$. Then, the analysis of variance (Anova) was carried out, and, when significant, the means were compared by the Tukey test at $5 \%$ of probability, using the Sisvar software (Ferreira 2011). Regression analysis was conducted as a function of the cultivation time.

\section{RESULTS AND DISCUSSION}

All AMF species exhibited an increased number of spores during the cultivation time (Figure 1), with variation occurring according to the AMF species and the evaluation time, with emphasis on species of the Acaulospora genus. The regression equations, coefficients of determination $\left(r^{2}\right)$ and significance of the regression coefficients are also shown in Figure 1. Such response of different AMF associated with the same host plant species is considered common, considering that the sporulation capacity is a characteristic of each fungus species, being influenced by the host plant when relating to the compatibility and efficiency of the plant/AMF symbiotic system (Klironomos et al. 2005).

The greatest potential for spore multiplication in $U$. brizantha was observed for $A$. longula followed by $A$. colombiana and $A$. morrowiae, producing 859,755 and 228 spores ( $50 \mathrm{~mL}$ of substrate),

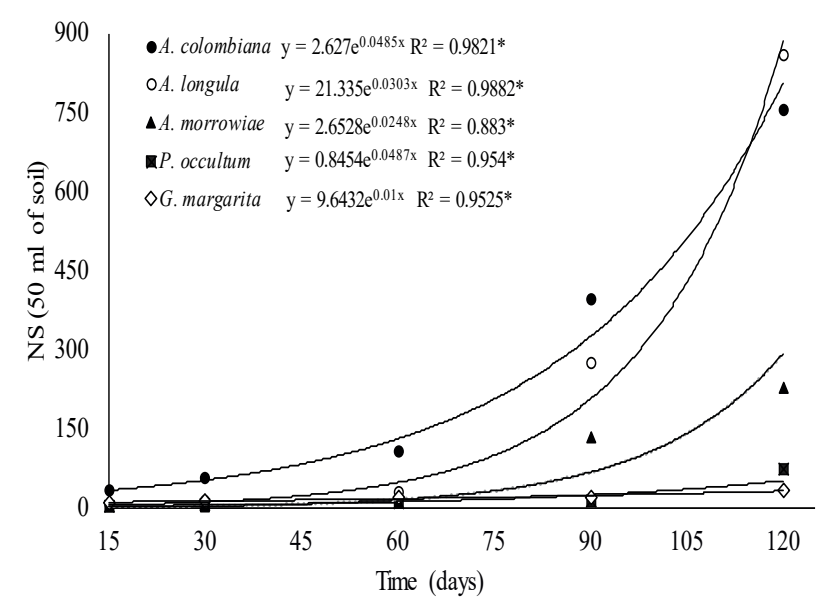

Figure 1. Number of spores (NS) of AMF species associated with Urochloa brizantha, as a function of the cultivation time $(15,30,60,90$ and 120 days of cultivation). $* \mathrm{p}<0.05$. 
respectively, at 120 days of cultivation, according to the regression equation (Figure 1). The high multiplication potential of A. longula in Urochloa plants is a typical characteristic of this kind of fungus, corroborating results found by Coelho et al. (2014). On the other hand, the lowest spore multiplication was observed for G. margarita and P. occultum, which exhibited, at 120 days of cultivation, 73 and 34 spores, respectively, in $50 \mathrm{~mL}$ of substrate (Figure 1). These results suggest that the use of $U$. brizantha as a multiplier of G. margarita and P. occultum would require a longer cultivation time (more than 120 days), as previously reported for G. margarita and G. gigantea (Oehl et al. 2009, Jiménez-Martínez et al. 2014).

The number of spores observed in this study shows the efficiency and infective potential of AMF of the Acaulospora genus, whose most species usually exhibit a high capacity of spore multiplication, a fact that confers a wide adaptation of the genus to the most different environments (Oehl et al. 2006). Furtheremoe, Acaulospora species are considered as having a more "aggressive" establishment, symbiosis formation and multiplication of infective propagules (Stürmer et al. 2006). This genus is very common in Brazilian soils, and the majority of the species are largely found in soils of tropical regions, distributed in different biomes in native and cultivated areas (Stürmer \& Siqueira 2011, Ferreira et al. 2012, Assis et al. 2014).

The spore multiplication varied according to the cultivation time and AMF, showing that there is a difference in the interaction of the fungus species when associated with the same host plant. These results suggest that, for the studied AMF, it is necessary a different cultivation period to achieve the maximum multiplication of AMF spores associated with $U$. brizantha. This behavior has also been observed when assessing the interaction of the same AMF associated with different host plants and substrates (Kadian et al. 2018), showing that, as well as the AMF physiology, the host plant genotype also influences the mycorrhizal symbiosis.

The spore density was proportional to the AMF mycorrhizal colonization, where $A$. colombiana achieved the greatest mycorrhizal colonization (30\%) in a shorter period of cultivation (at 76 days), followed by $A$. longula (around $35 \%$ of colonization at 96 days of cultivation), A. morrowiae ( $32 \%$ at 120 days), P. occultum (around $27 \%$ at 112 days) and
G. margarita (16\% of mycorrhizal colonization at 120 days of cultivation), according to the regression equations (Figure 2). These results indicate that there are differences between AMF species, with respect to the establishment of mycorrhizal symbiosis with $U$. brizantha, with emphasis for A colombiana, which showed the greatest colonization in a shorter cultivation time. On the other hand, the lowest mycorrhizal colonization was observed for G. margarita at 120 days (Figure 2).

For the inoculation with $P$. occultum, it was found a sporulation of 73 spores ( $50 \mathrm{~mL}$ of substrate), with $27 \%$ of mycorrhizal colonization at 112 days of cultivation, and, for G. margarita, 34 spores (50 mL of substrate) with $16 \%$ of colonization. The regression equations, coefficients of determination $\left(\mathrm{r}^{2}\right)$ and significance of the regression coefficients are also shown in Figures 1 and 2. The small number of spores for the species of the Gigaspora genus has also been reported in other studies, as by JiménezMartínez et al. (2014), who recorded 20 spores g ${ }^{-1}$ of substrate for G. gigantea.

Studies show that, for the Gigaspora species, a natural germination of spores occurs more slowly, sometimes requiring a longer period of "dormancy" of the spores in the soil (Gazey et al. 1993, Oehl et al. 2009). However, in the present study, such "dormancy" period for G. margarita was not observed, since the soil-inoculum was used immediately after the multiplication of the infective propagules used for the inoculation of the $U$. brizantha plants.

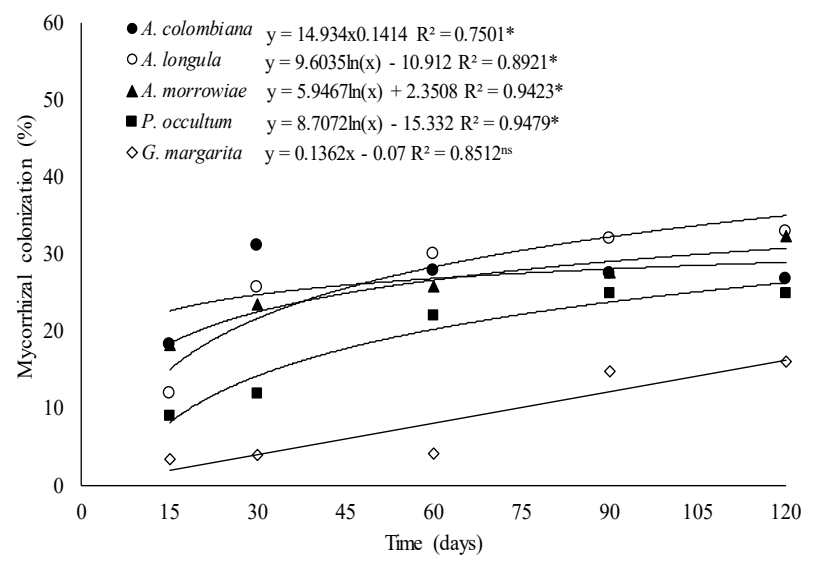

Figure 2. Mycorrhizal colonization of AMF species associated with Urochloa brizantha according to the cultivation time $(15,30,60,90$ and 120 cultivation days). * $\mathrm{p}<$ 0.05 . 
AMF species present different colonization strategies, according to the host plant species, cultivation conditions and characteristics of each AMF species (Siqueira \& Klauberg-Filho 2002, Parniske 2008, Stürmer \& Siqueira 2013). This behavior was found in the present study for A. colombiana, A. longula, A. morrowiae, P. occultum and G. margarita associated with $U$. brizantha. Although it is a plant species commonly used for AMF multiplication and cultivation in culture collections, it was found a variation in the symbiosis establishment according to the cultivation time and AMF species.

For the evaluations of $U$. brizantha growth, in general, it was found a higher inoculation effect with A. colombiana and A. longula $(\mathrm{p}<0.05)$ (Figures 3 and 4). The $U$. brizantha plants exhibited an increase of up to $91.1 \%$ for shoot dry matter when inoculated with $A$. longula, and $47.08 \%$ for $A$. colombiana at 120 days of cultivation, when compared with the non-inoculated plants.

Most of the inoculated AMF species, except for G. margarita, exhibited increased shoot dry matter volumes at 120 days of cultivation $(p<0.05)$ (Figures 3 and 4). In general, the lowest inoculation effect on the $U$. brizantha plants development was found for G. margarita (Figures 3 and 4). This behavior for G. margarita is related with the lower infective potential observed in the study, through the low sporulation rate, low mycorrhizal colonization and, consequently, a smaller effect on plant growth.

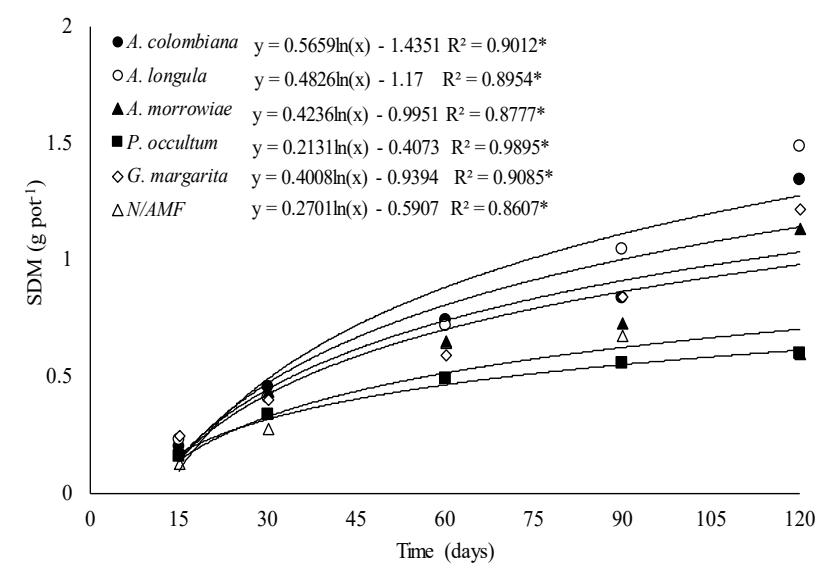

Figure 3. Shoot dry matter (SDM) of Urochloa brizantha inoculated with AMF species and treatment without inoculation (N/AMF) during the cultivation time $(15,30,60,90$ and 120 cultivation days). $* \mathrm{p}<0.05$.
On the other hand, the inoculation with A. longula and A. colombiana resulted in more increased amounts of root dry matter of $U$. brizantha at 120 days of cultivation. Root dry matter is a key variable, contributing to the soil organic carbon apportionment, especially in tropical soils, where erosion and organic matter decomposition rates are higher (Lal \& Logan 1995).

Carneiro et al. (1999) also found an increased production of root dry matter of $U$. decumbens in degraded areas, which raised from $3.5 \mathrm{Mg} \mathrm{ha}^{-1}$ to $26.7 \mathrm{Mg} \mathrm{ha}^{-1}$ of roots, when inoculated with AMF. The AMF capacity to enhance the growth of the Urochloa genus is another key aspect, due to the increased foliar biomass, which results in a greater photosynthetic activity (increased fixation of atmospheric $\mathrm{CO}_{2}$ ), favoring the accumulation of organic carbon by roots and, accordingly, increasing the nutrients flow and cycling in the soil/plant system (Wang et al. 2016). Furthermore, increases for shoot dry matter are a desirable condition, considering the importance of the Urochloa genus in the formation of pasture/forage crops for animal feed.

As observed for the multiplication of spores and root mycorrhizal colonization, different AMF species also showed distinct behaviors for increased glomalin concentration during the cultivation time, according to the regression equations (Figure 5), especially for inoculation with the Acaulospora species, with an increase of up to $40 \%$ for $A$. longula, A. colombiana and P. occultum, and $25 \%$ and $19 \%$ for A. morrowiae and G. margarita, when compared

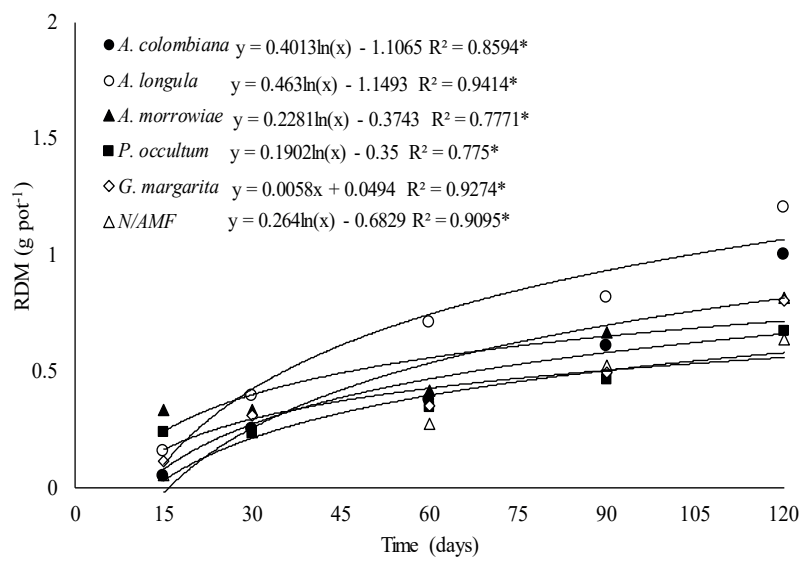

Figure 4. Root dry matter (RDM) of Urochloa brizantha inoculated with AMF species and treatment without inoculation $(\mathrm{N} / \mathrm{AMF})$ during the cultivation time $\left(15,30,60,90\right.$ and 120 cultivation days). ${ }^{*} \mathrm{p}<0.05$. 


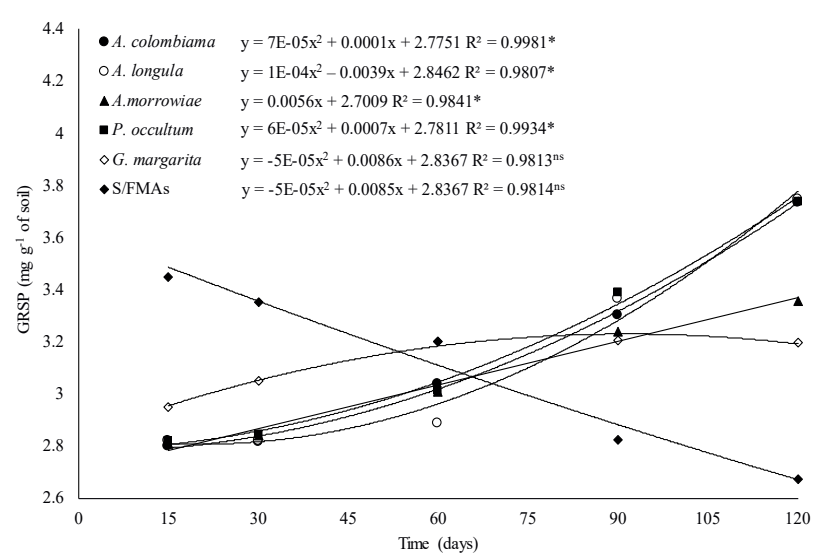

Figure 5. Production of easily-extractable glomalin-related soil protein (GRSP) produced by different AMF species associated with Urochloa brizantha, as found during the cultivation period $(15,30,60,90$ and 120 days). $* \mathrm{p}<0.05$.

with the soil not inoculated with AMF, whose initial concentration was $2.67 \mathrm{mg} \mathrm{g}^{-1}$ of glomalin in the soil. The glomalin-related soil protein content at 120 days of cultivation ranged from $3.74 \mathrm{mg} \mathrm{g}^{-1}$ to $3.30 \mathrm{mg} \mathrm{g}^{-1}$ of soil, respectively for the A. longula and G. margarita species, which exhibited a higher and lower glomalin-related soil protein concentration, respectively (Figure 5).

The reduced glomalin-related protein concentration in the soil samples not inoculated with AMF supports the fact that although glomalin is considered recalcitrant, degradation may occur over time by diverse factors present in the soil, especially by the soil microfauna activity (Figure 5).

The increased glomalin-related soil protein concentrations in the AMF-inoculated treatments represent an increase that ranged from $1,000 \mathrm{~kg} \mathrm{ha}^{-1}$ for G. margarita and 2,140 $\mathrm{kg} \mathrm{ha}^{-1}$ for A. longula. The accumulation of this glycoprotein in the soil is important due to its great capacity of retaining organic carbon, which contributes to the "reduction of the $\mathrm{CO}_{2}$ " emission, contributing to a greater apportionment of $\mathrm{C}$ and $\mathrm{N}$ in the soil organic fraction (Rillig et al. 2001, Cornis 2002, Wright \& Nichols 2002, Lehmann et al. 2017). Therefore, from a practical point of view, glomalin-related soil protein represents a major input of organic $\mathrm{C}$ into the soil system, which favors the increase of diversity and biological activity and contributes to an improved soil structure and quality.

In general, inoculation with $A$. longula showed the best response over time for the number of spores, a high root dry matter increase of up to $89 \%$ and shoot dry matter with $91 \%$, and, for glomalin-related soil protein, a $40 \%$ increase was recorded, representing a storage of up to $2,140 \mathrm{~kg} \mathrm{ha}^{-1}$ of glomalin.

The use of species of the Urochloa genus as an AMF-multiplier plant is already well-known, but still lacking information on the interactions of different AMF for mycorrhizal colonization and spore multiplication to be used in AMF collections. Thus, this study indicates that more information is needed for a better understanding of the symbiotic relationships between different AMF species associated with the same host plant, taking into account the large diversity of AMF species that are known.

These results provide information that may help to support a better management of native AMF, either in pasture or crop lands, for the production of inoculants or "trap cultivation" and for maintenance of AMF collections in germplasm banks.

\section{CONCLUSIONS}

1. Acaulospora colombiana exhibits the greatest mycorrhizal colonization in a shorter cultivation time, at 76 days;

2. The A. longula and A. colombiana species are more effective in producing spores after 120 days of cultivation with Urochloa brizantha;

3. Paraglomus occultum and Gigaspora margarita require more time of cultivation (over 120 days) for spore multiplication and mycorrhizal colonization of $U$. brizantha;

4. The highest concentration of glomalin is found in plants inoculated with $A$. longula, $A$. colombiana and $P$. occultum.

\section{ACKNOWLEDGMENTS}

The authors thank the Coordenação de Aperfeiçoamento de Pessoal de Nível Superior (Capes), Conselho Nacional de Desenvolvimento Científico e Tecnológico (CNPq) and Fundação de Amparo à Pesquisa de Minas Gerais (Fapemig), for the financial support and scholarships granted to the authors.

\section{REFERENCES}

ASSIS, P. C. R. et al. Fungos micorrízicos arbusculares em campos de murundus após a conversão para sistemas 
agrícolas no Cerrado. Revista Brasileira de Ciência do Solo, v. 38, n. 6, p. 1703-11, 2014.

BRADFORD, M. M. A. Rapid and sensitive method for the quantitation of microgram quantities of protein utilizing the principle of protein-dye binding. Analytical Biochemistry, v. 72, n. 2, p. 248-254, 1976.

BÜCKING, H.; MENSAH, J. A.; FELLBAUM C. R. Common mycorrhizal networks and their effect on the bargaining power of the fungal partner in the arbuscular mycorrhizal symbiosis. Communicative and Integrative Biology, v. 9, n. 1, p. 1-5, 2016.

CARNEIRO, M. A. C. et al. Efeito da inoculação e fungos micorrízicos arbusculares e da aplicação de fósforo no estabelecimento de forragens em solo degradado. Pesquisa Agropecuária Brasileira, v. 34, n. 9, p. 1669-1677, 1999.

COELHO, I. R. et al. Optimization of the production of mycorrhizal inoculum on substrate with organic fertilizer. Journal of Microbiology, v. 45, n. 4, p. 1173-1178, 2014.

CORNIS, D. G. Hiding place for a third of the world's stored soil carbon. Agricultural Research, v. 50, n. 2, p. 4-16, 2002.

DALPE, Y.; SEGUIN, S. A. "Paper bridge" system to improve in-vitro propagation of arbuscular mycorrhizal fungi. Botany, v. 88, n. 6, p. 617-620, 2010.

FERREIRA, D. A.; CARNEIRO, M. A. C.; SAGGINJUNIOR, O. J. fungos micorrízicos arbusculares em um Latossolo Vermelho sob manejos e usos no Cerrado. Revista Brasileira de Ciencia do Solo, v. 36, n. 1, p. 51-61, 2012.

FERREIRA, D. F. Sisvar: a computer statistical analysis system. Ciencia e Agrotecnologia, v. 35, n. 6, p. 10391042, 2011.

GAZEY, C.; ABBOTT, K. K.; ROBSON, A. D. V. A. Mycorrhizal spores from 3 species of Acaulosporagermination, longevity and hyphal growth. Mycological Research, v. 96, n. 8, p. 785-790, 1993.

GERDEMANN, J. W.; NICOLSON, T. H. Spores of mycorrhizal Endogone species extracted from soil by wet sieving and decanting. Transactions of the British Mycological Society, v. 46, n. 2, p. 235-244, 1963.

GIOVANNETTI, N.; MOSSE, B. An evaluation of techniques to measure vesicular-arbuscular infection in roots. New Phytologist, v. 84, n. 3, p. 489-500, 1980.

JENKINS, W. R. A rapid centrifugal-flotation technique for separating nematodes from soil. Plant Disease Reporter, v. 48, n. 9, p. 692, 1964.

JIMÉNEZ-MARTÍNEZ, A. et al. Producción de inóculo micorrízico de Gigaspora gigantea en mezclas de sustratos con diferente tamaño de partícula. Agrociencia, v. 48, n. 3, p. 239-254, 2014.
KADIAN, N. et al. Mass multiplication of arbuscular mycorrhizal fungi associated with some leguminous plants: an ecofriendly approach. Indian Journal of Experimental Biology, v. 56, n. 4, p. 258-266, 2018.

KLIRONOMOS, J. N. et al. Abrupt rise in atmospheric $\mathrm{CO}_{2}$ overestimates community response in a model plantsoil system. Nature, v. 433, n. 7026, p. 621-624, 2005.

LAL, R.; LOGAN, J. Agricultural activities and greenhouse gas emissions from soils of the tropics. In: LAL, R. et al. (Eds.). Soil management greenhouse effect. Boca Roton: CRC Press, 1995. p. 293-307.

LEHMANN, E. F. et al. Mycorrhizas and soil aggregation mycorrhizal. Mediation of Soil, v. 1, n. 1, p. 241-262, 2017.

OEHL, F. et al. Acaulospora alpina, a new arbuscular mycorrhizal fungal species characteristic for high mountainous and alpine regions of the Swiss Alps. Mycologia, v. 98, n. 1, p. 86-94, 2006.

OEHL, F. et al. Distinct sporulation dynamics of arbuscular mycorrhizal fungal communities from different agroecosystems in long-term microcosms. Agriculture, Ecosystems and Environment, v. 134, n. 3, p. 257-268, 2009.

PARNISKE, M. Arbuscular mycorrhiza: the mother of plant root endosymbioses. Nature Reviews Microbiology, v. 6, n. 10, p. 763-75, 2008.

PHILLIPS, J. M.; HAYMAN, D. S. Improved procedures for clearing roots and staining parasitic and vesiculararbuscular mycorrhizal fungi for rapid assessment of infection. Transactions of the British Mycological Society, v. 55 , n. 1 , p. $158-161,1970$.

PURIN, S. Fungos micorrizicos arbusculares: atividade, diversidade e aspectos funcionais em sistemas de produção de maçã. 2005. 152 f. Dissertação (Mestrado em Ciência do Solo) - Universidade do Estado de Santa Catarina, Lages, 2005.

RILLIG, M. C. et al. Elevated carbon dioxide and irrigation effects on water stable aggregates in a Sorghum field: a possible role for arbuscular mycorrhizal fungi. Global Change Biology, v. 7, n. 3, p. 333-337, 2001.

SCHLEMPER, R. T.; STÜRMER, S. L. On farm production of arbuscular mycorrhizal fungi inoculum using lignocellulosic agrowastes. Mycorrhiza, v. 24, n. 8, p. 571-580, 2014.

SELVAKUMAR, G. et al. Arbuscular mycorrhizal fungi spore propagation using single spore as starter inoculum and a plant host. Journal of Applied Microbiology, v. 124, n. 6 , p. 1-27, 2018.

SIQUEIRA, J. O. et al. Micorrizas: 30 anos de pesquisa no Brasil. Lavras: Ed. UFLa, 2010. 
SIQUEIRA, J. O.; KLAUBERG-FILHO, O. Micorriza arbuscular: a pesquisa brasileira em perspectivas. Tópicos em Ciência do Solo, v. 1, n. 1, p. 235-264, 2002.

SMITH, S. E.; READ, D. J. Mycorrhizal symbiosis. London: Academic Press, 2008.

STÜRMER, S. L. et al. Occurrence of arbuscular mycorrhizal fungi in soils of early stages of a secondary succession of Atlantic Forest in South Brazil. Acta Botanica Brasilica, v. 20, n. 3, p. 513-521, 2006.

STÜRMER, S. L.; SIQUEIRA, J. O. Fungos micorrízicos. In: MOREIRA, F. M. S. (Ed.). O ecossistema solo. Lavras: Ed. UFLa, 2013. p. 291-310.

STÜRMER, S. L.; SIQUEIRA, J. O. Species richness and spore abundance of arbuscular mycorrhizal fungi across distinct land uses in western Brazilian Amazon. Mycorrhiza, v. 21, n. 4, p. 255-67, 2011.

USA. Soil Survey Staff. Soil taxonomy: a basic system of soil classification for making and interpreting soil surveys. 2. ed. Washington, DC: USDA, 1999.

WANG, Z-G. et al. Arbuscular mycorrhizal fungi enhance soil carbon sequestration in the coalfields, northwest China. Scientific Reports, v. 6, n. 34336, p. 1-11, 2016.

WRIGHT, S. F.; NICHOLS, K. A. Glomalin: hiding place for a third of the world's stored soil carbon. Agricultural Research, v. 50, n. 1, p. 4-7, 2002.

WRIGHT, S.; UPADHYAYA, A. A survey of soils for aggregate stability and glomalin, a glycoprotein produced by hyphae of arbuscular mycorrhizal fungi. Plant and Soil, v. 198 , n. 1, p. 97-107, 1998. 